\title{
A CONVENÇÃO INTERNACIONAL SOBRE OS DIREITOS DA CRIANÇA: DEBATES E TENSÕES
}

\author{
FÚLVIA ROSEMBERG \\ Professora de Psicologia Social da Pontifícia Universidade Católica de São Paulo, \\ coordenadora do Núcleo de Estudos de Gênero, Raça e Idade, \\ pesquisadora do Departamento de Pesquisas Educacionais da Fundação Carlos Chagas, \\ coordenadora da sessão brasileira do Programa Internacional de Bolsas \\ de Pós-Graduação da Fundação Ford \\ frosemberg@fcc.org.br
}

\section{CARMEM LÚCIA SUSSEL MARIANO}

Doutoranda do Programa de Estudos Pós-Graduados em Psicologia Social da Pontifícia Universidade Católica de São Paulo sussel@uol.com.br

\section{RESUMO}

Neste artigo, revisitamos a literatura sobre o contexto sociopolítico e o texto da Convenção Internacional sobre os Direitos da Criança, bem como algumas de suas repercussões no Brasil. Nosso interesse de apresentar e discutir a literatura sobre a Convenção decorre não só da escassez da bibliografia brasileira, apesar da célere ratificação do documento pelo Brasil e de ele ter inspirado a elaboração do art. 227 da Constituição Brasileira de 1988 e do Estatuto da Criança e do Adolescente. Deriva, sobretudo, de sua inovação na representação de infância e dos direitos da criança e, em consequência, da intensa e instigante produção acadêmica que tem provocado no hemisfério norte. Além disso, parece-nos urgente que a sociedade brasileira disponha de embasamento mais consistente sobre os marcos legais que adota.

DIREITOS DA CRIANÇA E DO ADOLESCENTE - POLITICAS PÚBLICAS - ASSISTÊNCIA À INFÂNCIA - CRIANÇAS

\begin{abstract}
THE INTERNATIONAL CONVENTION ON THE CHILD'S RIGHTS: DEBATES AND TENSIONS. In this article, we look again at literature relating to socio-political contexts and the text of the International Convention on the Rights of the Child, as well as some of its repercussions in Brazil. Our interest in presenting and discussing the literature on the Convention stems not only from the fact that little has been written in Brazil on this theme, despite its speedy ratification of the document, and the fact that it inspired the drafting of Article 227 of the 1988 Brazilian Constitution and the Statute of the Child and Adolescent. It derives above all, from the way it innovated in representing childhood and children's rights and, as a consequence, the intense
\end{abstract}


and challenging academic production it provoked in the northern hemisphere. Furthermore, it seems for us that Brazilian society urgently needs to have a more consistent basis for the legal frameworks it adopts.

RIGHTS OF THE CHILD AND ADOLESCENT - POLICIES - CHILD WELFARE - CHILDREN

Longo tem sido o percurso histórico das instituições sociais, inclusive jurídicas e acadêmicas, para que os adultos das sociedades ocidentais reconhecessem, à criança, o estatuto de sujeito e a dignidade de pessoa. Dentre os marcos fundantes desse reconhecimento destacam-se a Declaração Universal dos Direitos da Criança promulgada pela Organização da Nações Unidas ONU -, em 1959, e a publicação do livro de Philippe Ariès (1961), L'enfant et la vie familiale sous l'ancien régime. Apesar de críticas que lhes foram feitas, ambos os textos instalaram discursos e práticas sobre a infância e as crianças contemporâneas.

Ariès ( 196 |), ao inaugurar a "visão da infância como uma construção social, dependente ao mesmo tempo do contexto social e do discurso intelectual" (Sirota, 200 I , p. I0), lança as bases para a mudança paradigmática proposta, nas décadas de 1980 e 1990, pelos Estudos Sociais sobre a Infância (na tradição anglosaxônica), ou Sociologia da Infância (na tradição francófona). Trata-se de alçar a infância à condição de objeto legítimo das Ciências Humanas e Sociais; entender a infância como uma construção social; romper com o modelo "desenvolvimentalista" da Psicologia (por exemplo, o piagetiano) "impelido para uma estrutura de racionalização adulta permanentemente definida" (Jenks, 2002, p.2 I2); atacar o conceito de socialização da criança como inculcação, até então predominante na Antropologia, na Psicologia e na Sociologia; conceber a criança como ator social.

Essa nova perspectiva de compreensão da infância rompeu com tendências principais então vigentes na produção teórica e no contexto sociopolítico de discursos e práticas referentes à infância e que envolve crianças. As críticas de James e Prout (2003), bem como as de Jenks (2002) ou Corsaro (1997), ao tratamento dado à infância no arcabouço teórico funcionalista são contundentes: teorias funcionalistas, às voltas com a explicação da ordem social, adotam uma concepção de infância a seu serviço, passível apenas de explicar a reprodução social. Pouca atenção é dada à contradição e ao conflito: uma criança ou se conforma, ou é tida como desviante. Dessa perspectiva, as teorias não ofereceriam um quadro interpretativo para compreender a infância, ao contrário, 
adotariam uma concepção de infância que permitia manter o arcabouço teórico assentado no pressuposto metateórico do equilíbrio.

A nova produção teórica foi angariando adeptos, inicialmente nos países do hemisfério norte, tendo sido reconhecida como campo legítimo de produção acadêmica em 1990, quando a International Sociological Association criou um grupo de trabalho sobre Sociologia da Infância. Ela também informou discussões sobre direitos da criança que percorreram as décadas de 1970 e 1980.

No Brasil, a despeito de alguns textos percussores na Educação (Cadernos de Pesquisa, 1979), na História (Priore, 1991), na Sociologia (Fernandes, 1979) e na Psicologia (Rosemberg, 1976), essa nova abordagem acadêmica é bem mais recente, datando especialmente desta década, mas já sendo abrigada em diversas associações de pós-graduação e campos acadêmicos: Antropologia (Cohn, 2005), (Delgado e Müller, 2005), História (Freitas, Kuhlmann Jr., 2002), Psicologia (Castro, 200 I), Sociologia (Marchi, 2009).

Apesar de nos inspirar, temos problematizado alguns aspectos desse enfoque teórico: eventuais diferenças conceituais e políticas que o termo criança possa recobrir em línguas que dispõem de dois termos diferentes para puer e filius - como no português, criança e filho - e nas que dispõem de apenas um (inglês ou francês, por exemplo); qual a idade da criança da Sociologia da Infância diante da complexidade ao enfrentarmos a alteridade do bebê e o modo de concebê-lo como ator social? Qual o estatuto epistemológico do conceito de infância: trata-se de categoria descritiva ou analítica? Como integrar as relações de idade na compreensão de arranjos políticos e jurídicos nacionais e supranacionais? Apesar de reconhecer inúmeras lacunas, adotamos a perspectiva teórica de que as relações de idade (e não a infância) constituem categoria analítica útil para se compreender a produção e sustentação de desigualdades sociais.

Assim, entendemos a delimitação das etapas da vida também como uma construção social que, no ocidente contemporâneo, hierarquiza as idades, posicionando o adulto como ápice desta hierarquia. Nesse sentido, ao lado das hierarquias de classe, gênero, raça-etnia e nação, as categorias etárias também configuram relações de dominação. Porém, as relações de dominação não atuam de forma sincrônica, seja na trajetória social, seja na história individual. Isso significa, por exemplo, que a busca de compreensão e superação de relações de dominação de classe (ou de gênero, raça-etnia, nação) pode gerar ou sustentar relações de dominação de idade. Por exemplo, mesmo teorias 
feministas contemporâneas, que romperam com a máxima essencialista na compreensão das relações de gênero, podem sustentar a naturalização da infância ao assumir, sem problematização, a máxima da imaturidade biológica da criança. Que se tenha, contudo, claro: nosso questionamento não significa negar a imaturidade biológica, mas discutir "como as culturas interpretam tal imaturidade" (Prout, James, 1990, p.7)'.

Nossa perspectiva analítica se distancia de interpretações contemporâneas que anunciam "o fim da infância" (Postman, 1999). Argumentamos que, nas sociedades contemporâneas, apesar de cada vez mais afastada da produção econômica, a infância produz recursos econômicos, é "útil”. Em primeiro lugar, a demarcação de sua especificidade dinamiza os mercados de trabalho e de consumo. Ao se the reconhecerem necessidades (ou direitos) específicas(os), geram-se novas profissões no mercado de trabalho adulto que, por sua vez, geram, também, a produção de novas mercadorias e serviços, inclusive os de natureza política, acadêmica, filantrópica, comunitária, ou solidária. Oldman ( 1 994) assinala esse valor econômico da infância com base no que denomina "trabalho para criança" [childwork], "isto é, trabalho realizado por adultos na organização e controle das atividades infantis" (p.45). Portanto, nossas sociedades sucumbiriam à não demarcação da infância e de suas instituições específicas. Que se pense na hecatombe econômica se a escola básica - instituição de massa para crianças e adolescentes - desaparecesse.

Este exemplo remete à segunda razão da "utilidade" econômica da infância: sua atividade de aluno, de escolar.

Contrariamente à visão daqueles que consideram as crianças na modernidade como inúteis, elas ganharam uma nova importância na esteira da modernização [...] Seu tempo e suas atividades foram exigidos e portanto colonizados pelo novo método de produção e consequentemente elas caminharam em massa para os locais universalmente estabelecidos para o trabalho da criança moderna - a escola. (Qvortrup, 200I, p. 139)

Entre as dificuldades para aceitar a configuração adultocêntrica das sociedades contemporâneas, destacamos o hábito de pensar a infância, prefe-

I. Ver artigo de Prout neste número (p.729-750). 
rencialmente em contexto familiar. Assim, parece ocorrer um deslizamento de sentido de criança para filho(a), particularmente nas línguas que não diferenciam puer de filius. É como se a generosidade de pais e mães pelo(a) filho(a) se expandisse "naturalmente" para toda e qualquer criança ${ }^{2}$. Ao subsumir, no entanto, a criança no filho, circunscreve-se a infância à esfera do privado, da família, da casa e das relações interpessoais. A prática contemporânea de prover instituições organizadas por classes de idade (creches e escolas), o que Ariès (1961) denominou enclausuramento das crianças, e de controlar o espaço da rua, reforça a reduzida visibilidade pública de crianças, especialmente das menores, dos bebês. A infância e a adolescência ascendem à visibilidade pública preferencialmente quando associadas à excepcionalidade, ao "desvio", ao drama, à violência (Hilgartner, Bosk, 1988).

E a forma pela qual a infância adentra a esfera pública é crucial para a posição que ocupa na arena de negociação das políticas públicas - inclusive dos marcos legais nacionais e internacionais, como a Convenção Internacional sobre os Direitos da Criança. Isso porque concebemos a agenda de políticas públicas também como uma construção social e política, resultante do jogo de tensões e coalizões entre diversos atores sociais, nacionais e internacionais, incluindo aqui as agências multilaterais e fundações. Nesse sentido, os problemas sociais que incitam a atenção pública podem também ser entendidos como socialmente construídos (Lahire, 2005; Rosemberg, Andrade, 2007). Hierarquizamos problemas sociais conforme padrões éticos, políticos, orientações ideológicas, interesses pessoais ou corporativos. A despeito de nossas motivações, a construção da agenda de problemas sociais, no mundo contemporâneo, depende intensamente das mídias, que atuam tanto em seu próprio nome, quanto como caixa de ressonância de outros atores sociais. A midiatização das sociedades modernas, mais enfaticamente das contemporâneas, penetra as diversas instituições, entre elas a política (Thompson, 1995), o ativismo social e a academia (Sánchez-Jankowiski, 1997). Para o bem e para o mal, vivemos uma era da política espetáculo (Lipowetsky, 1989) que atinge (e por vezes configura) a agenda de políticas sociais.

Para incitar a atenção pública, nós, defensores de causas sociais, construímos um discurso apoiado na persuasão, buscando convencer o público quanto

2. A partir deste ponto, o texto abandona a fórmula o(a), visando a maior fluência. 
à relevância das causas que nos mobilizam. Alguns de nós privilegiam o drama. E a dramaticidade de uma necessidade humana tem sido intensificada pelo uso retórico da criança, especialmente quando associada à violência, como vítima ou algoz (Best, 2008).

Nós, profissionais, políticos, ativistas e acadêmicos da causa da infância, com frequência ultrapassamos o limite, que pode ser tênue, entre a publicização de uma necessidade social intensa e a dramatização espetacular de um problema social. O risco, que pode decorrer dessa passagem, é a canalização de recursos humanos e financeiros para o espetáculo, em detrimento de outras urgências com menor apelo midiático.

Foi com esse olhar que revisitamos a literatura sobre o contexto sociopolítico e o texto da Convenção Internacional sobre os Direitos da Criança, bem como algumas de suas repercussões no Brasil. Apesar do reconhecimento de sua importância no (e pelo) Brasil, a bibliografia acadêmica brasileira é reduzida. Nosso interesse em apresentar e discutir a literatura sobre a Convenção decorre não só da escassez da bibliografia brasileira, apesar de sua célere ratificação pelo Brasil e sua inspiração na elaboração do art. 227 da Constituição Federal Brasileira - CF -, de 1988³, bem como do Estatuto da Criança e do Adolescente - ECA - e, sobretudo, de sua inovação na representação de infância e dos direitos da criança e, em consequência, da intensa e instigante produção acadêmica que tem provocado no hemisfério norte.

Isso porque parece urgente que a sociedade brasileira, e principalmente os gestores, disponham de embasamento consistente e sustentado em debates mais democráticos sobre marcos legais que adotam. Exemplos recentes de emendas constitucionais - EC - e projetos de lei, elaborados e votados pelo parlamento brasileiro, sugerem essa necessidade. Por exemplo, no encaminhamento da EC 59/09 que institui a obrigatoriedade de matrícula/frequência na pré-escola, observamos que, na Câmara Federal e no Senado, a tendência dominante, também por desconhecimento das bases históricas e filosóficas, foi entender obrigatoriedade como universalização da oferta (Rosemberg, 20 l0).

3. "É dever da família, da sociedade e do Estado assegurar à criança e ao adolescente, com absoluta prioridade, o direito à vida, à saúde, à alimentação, à educação, ao lazer, à profissionalização, à cultura, à dignidade, ao respeito, à liberdade e à convivência familiar e comunitária, além de colocá-los a salvo de toda a forma de negligência, discriminação, exploração, violência, crueldade e opressão" (Brasil, 1988, art. 227). 
A Convenção de 1989, em relação às declarações internacionais anteriores, inovou não só por sua extensão, mas porque reconhece à criança (até os 18 anos) todos os direitos e todas as liberdades inscritas na Declaração dos Direitos Humanos. Ou seja, pela primeira vez, outorgaram-se a crianças e adolescentes direitos de liberdade, até então reservados aos adultos. Porém, a Convenção de 1989 reconhece, também, a especificidade da criança, adotando concepção próxima à do preâmbulo da Declaração dos Direitos da Criança de 1959: "a criança, em razão de sua falta de maturidade física e intelectual, precisa de uma proteção especial e de cuidados especiais, especialmente de proteção jurídica apropriada antes e depois do nascimento".

Analistas da Convenção de 1989 discutem suas tensões intrínsecas, especialmente sob duas perspectivas: sua pretensão universal, mas seu viés ocidental captado pela ênfase aos direitos individuais (Boyden, 1997); a promulgação simultânea de direitos à proteção, à provisão e de direitos de liberdade, expressão e participação (Soares, 1997).

A tensão entre diferentes concepções de direitos da criança, observada na Convenção de 1989, tem provocado instigante debate entre filósofos, juristas e sociólogos, especialmente europeus. Desse debate emergem duas posições: por um lado, um compromisso com a vertente da proteção,

... sustentada pela ideia que a educação seria a única via que pode tirar a criança de sua vulnerabilidade para que tenha acesso à autonomia; por outro, uma corrente defendida pelos "artesãos da autodeterminação" que pedem uma mobilização em torno dos direitos do homem na criança. (Théry, apud Sirota, 200 I, p.20)

Esta última denominada, comumente, posição filosófico-política "protecionista" (ou paternalistas) e "liberacionista" (ou autonomista). Conforme foi possível rastrear, tais posições, cristalizadas pelos debates em torno da Convenção de 1989, se conformaram muito mais cedo no século $X X$.

\section{PRECURSORES DO SÉCULO XX}

No artigo originalmente escrito em 1987, "A era dos direitos", Bobbio põe em evidência "como ocorreu a ampliação do âmbito dos direitos do homem na passagem do homem abstrato ao homem concreto através de um 
processo de gradativa diferenciação ou especificação" ( 1992, p.3) de quem seja esse "homem", esse cidadão. Essa especificação ocorreu em relação ao gênero, "aos estados normais e excepcionais" e com respeito "às várias fases da vida", mencionando como exemplo a Declaração dos Direitos da Criança. Esta Declaração de 1959, sob os auspícios da Organização das Nações Unidas - ONU -, e a precedente, de 1924, conhecida como a Declaração de Genebra, sob os auspícios da Liga das Nações, tiveram como foco defender a ideia de proteção à criança (Renaut, 2002).

Porém, a literatura se refere a duas iniciativas anteriores, datadas da primeira década do século $X X$ no leste europeu: os textos do polonês Janusz Korczak, de 1919 e 1929, e a Declaração dos Direitos das Crianças elaborada pela sessão moscovita da organização Proletkult, importante centro de produção e difusão cultural criado logo após a revolução de outubro, de 1917, esta última raramente mencionada. Diferentemente das declarações internacionais, ambas as iniciativas adotaram perspectiva liberacionista em relação aos direitos da criança. A declaração da Proletkult garantia que as crianças pudessem escolher como seriam educadas, que religião abraçariam ou se viveriam com seus pais (Mally, 1990).

Contrariamente à declaração da Proletkult, os textos de Janusz Korczak, bem como sua biografia, foram amplamente divulgados na Europa, particularmente após os movimentos contraculturais dos anos 1960. Korczak (I8781942), pseudônimo de Henryk Goldshmid, judeu polonês, médico pediatra por formação e educador por opção, criou em 1912, em Varsóvia, uma instituição (Lar de Crianças da Rua Krochalna) na qual acolhia, principalmente, crianças pobres judias. Em parceria com Stefa Wilczinska, implantaram uma organização da instituição governada pelas próprias crianças, o que incluía um parlamento e um tribunal.

Para Korczak, as crianças eram uma classe oprimida: "As crianças, afinal, são ou não seres humanos? [...] Para nós [falando como se fosse uma criança], não existem direitos nem justiça [...] Somos uma classe oprimida" (Korczak, 1987, p. II2-1 |4). Na 2a edição de sua principal obra, Como amar uma criança, Korczak ( 1929 ) argumentava que "o principal e mais indiscutível dos direitos da criança é o que the permite exprimir livremente suas ideias e tomar parte ativa no debate sobre a apreciação de sua conduta e punição". Ainda, no folheto publicado em anexo à mesma obra, $O$ direito da criança 
ao respeito ${ }^{4}$, manifestava dura crítica à Declaração de 1924: "Os legisladores de Genebra confundiram as noções do direito e do dever: o tom da Declaração salienta a solicitação e não a exigência. É um apelo à boa vontade, um pedido de compreensão".

Uma magna charta libertatis era o que Korczak já defendia em I9।5, na primeira edição de Como amar uma criança. Para ele, os direitos das crianças deveriam repousar sobre alguns aspectos essenciais: "o direito da criança a viver sua vida atual" e "o direito da criança a ser o que é". O amor de Korczak às crianças foi incondicional: acompanhou-as ao gueto de Varsóvia e ao campo de Treblinka, onde foram assassinados pelo terror nazista.

Após as manifestações pioneiras da Europa do Leste, observamos um longo silêncio na literatura sobre a defesa de posições liberacionistas até os movimentos contraculturais entre os anos 1960 e 1970. Na Europa, as revisões bibliográficas sobre a emergência da Sociologia da Infância (Sirota, 200 I; Montandon, 200 I) ignoram o tema; o período foi, também, ignorado no abrangente trabalho de Renaut (2002). O extensivo capítulo de Becchi ( 1998 ), no volume 2, de Histoire de l'enfance en Occident, sobre o século XX, simplesmente ignora os precursores liberacionistas e a Convenção de 1989. Isso não significa que a questão tenha estado afastada de discursos e práticas européias. Lembremos, por exemplo, o livro de Gérard Mendell (1972) Pour décoloniser l'enfant: sociopsychanalise de l'autorité.

Mendell (1972), sustentando-se em uma análise da autoridade nas sociedades contemporâneas, propôs a substituição de relações hierárquicas entre adultos e crianças, por relações de reciprocidade, igualitárias (entre classes de idade e não interindividuais), que teriam como garantia legal a antecipação para a idade de 12 anos do direito de votar ${ }^{5}$. É necessário, ainda, lembrar da inovação norueguesa ao se criar, pela primeira vez na história da humanidade,

4. No Brasil, esse texto foi publicado em livro com o mesmo título (Dallari, Korczak, 1986) e precedido, nessa edição, de outro texto, "Os direitos da criança", de autoria de Dalmo de Abreu Dallari ( 1986). O direito da criança ao respeito foi resenhado em número especial de Cadernos de Pesquisa (n. 31 , p. 103-104), alusivo ao Ano Internacional da Criança, em 1979, talvez a primeira menção à obra de Korczak no Brasil.

5. Ver resenha de Suzanne Mollo (1972). 
uma defensoria para as crianças em I 981, nos moldes da que já existia, naquele país, para a igualdade de gênero ${ }^{6}$.

Porém, do outro lado do Atlântico Norte, especialmente nos EUA, a década de 1970 assistiu a uma produção instigante (e inovadora) de tendência liberacionista, que se diferenciava do movimento pelos direitos da criança ${ }^{7}$.

....os libertadores das crianças não devem incorrer no erro de acreditar que a liberação e os direitos das crianças apresentam os mesmos objetivos. O movimento pelos direitos das crianças luta pelas crianças que aceitam sua proteção especial, como participantes desiguais da vida social. Os libertadores das crianças frequentemente parecem desejar o contrário: a liberação das crianças até mesmo da autoridade bem intencionada dos adultos e sua exposição aos mesmos direitos e privilégios dos adultos, com base em que a proteção que a elas proporcionam, na verdade lhes extorquem muitos direitos como cidadãos. (Berger, 1984, p.224)

Dentre os autores liberacionistas do período, são mais frequentemente citados os norte-americanos Richard Farson (1 974), John Holt (1974) e Howard Cohen (1980), considerados por Franklin (2002) os verdadeiros "pais" dos denominados novos paradigmas nos estudos da infância.

Em Birthrights: a bill of rights for children (1974), Richard Farson, educador, assinala que, no contexto da sociedade norte-americana, as crianças são segregadas, ignoradas, impotentes e invisíveis para a nação. Defende que as crianças deveriam ter o direito de participar na sociedade e que deveriam ser valorizadas pelo que são e não somente como um potencial adulto. Critica os defensores das crianças que se centram no abuso e na vitimização, os quais

6. Ver entrevista concedida por Maalfrid G. Flekkoiy a Peter Moss (2009), primeira defensora da criança na história ocidental.

7. De muito interesse é a leitura dos dois volumes sucessivos (43 e 44) da Harvard Educational Review (1973 e 1974), posteriormente reunidos em um único volume: The rights of children ( 1974). O volume se inicia com reflexivo artigo de Hillary Rodham, posteriormente conhecida como Hillary Clinton, e permite apreender-se a emergência de nova concepção sobre a infância na produção acadêmica e na prática jurídica norte-americanas.

8. O artigo de Bennett M. Berger é datado originalmente de 1977, mas foi publicado em português, em 1984, em coletânea. 
seriam responsáveis pelo notável aumento da legislação protecionista para as crianças. Predica a liberação das crianças no mundo que está organizado contra elas, que as mantém fracas, dominadas, ignoradas. Nesse mundo, o reconhecimento de direitos civis e políticos para as crianças poderia ser um instrumento dessa liberação.

Em Escape from childhood: the needs and rights of children (1974), John Holt, psicólogo, adota concepções de infância e de defesa de seus direitos muito próximas daquelas de Farson. Considera as crianças um grupo oprimido e a experiência da infância, para a maioria das crianças, muito similar à de uma prisão: o "jardim murado" da infância, em vez de proteção das asperezas do mundo exterior, pode significar confinamento e humilhação. Diferentemente de Farson ( 1974), utiliza mais o termo young people do que child. Daí, possivelmente, sua postura um pouco mais contundente daquela de Farson: propõe a equalização da lei para adultos e crianças/jovens, tornando disponível, para os young people, direitos, privilégios, deveres e responsabilidades dos cidadãos adultos.

A revisão bibliográfica nos permitiu apreender, também, uma certa evocação e referência mútua entre os movimentos de liberação das mulheres, dos negros (nos EUA) e das crianças. Um exemplo notável provém do livro de Shulamith Firestone (1976), A dialética do sexo: um manifesto da revolução feminista, de 1970, no qual a autora, feminista radical norte-americana, após constatação de destino equivalente entre mulheres e crianças nas sociedades capitalistas, propõe, entre seus quatro princípios revolucionários:

2) a total autodeterminação, incluindo a independência econômica, tanto das mulheres, quanto das crianças; 3 ) a total integração das mulheres e das crianças em todos os níveis da sociedade; 4) liberdade para todas as mulheres e crianças usarem a sua sexualidade como quiserem. (1976, p.235-237)

Firestone não constituía exceção: experiências em comunidades hippies entre os anos de 1960 a 1970 suscitaram práticas e pesquisas relacionadas a "novas" formas de relacionamento adulto-criança, ditas libertárias, inclusive no campo da sexualidade (Berger, 1984). Foi somente no decorrer da década de 1970 que se instalou, especialmente nos EUA, a forte tendência de denúncia e prevenção ao abuso contra crianças, inclusive o sexual, atributo que seria, com certeza, imputado às experiências comunitárias autodenominadas libertárias. 
Em oposição à corrente liberacionista, a protecionista, por razões filosóficas e políticas, se contrapõe à premissa de que crianças sejam sujeitos dos mesmos direitos outorgados aos adultos, apoiando-se em três assertivas: as crianças não dispõem das mesmas capacidades que qualificam os adultos para usufruto de direitos; a retórica do direito não captura a verdade sobre a vida das crianças e de suas famílias e encoraja uma permissividade destrutiva que tem consequências nefastas para adultos, crianças e sociedade; a negação desses direitos não tem impacto negativo na vida das crianças (síntese, a partir de tradução livre da Stanford encyclopedia of philosophy, 2006, p. 10)9. Duas filósofas de escol são frequentemente evocadas na defesa de tal posição antes da promulgação da Convenção Internacional sobre os Direitos da Criança Hannah Arendt e Onora O'Neill -, cujos argumentos continuam sendo revisitados na atualidade.

As posições de Hannah Arendt contrárias a uma tendência igualitarista no tratamento à criança foram brevemente tratadas no texto Entre o passado e o presente, de 1954. A partir de sua análise da modernidade, Arendt ataca as ideias que estariam sustentando a crise da educação: "A primeira [...] [estipula que] existe um mundo da criança e uma sociedade formada entre as crianças que são autônomas e que se deve, na medida do possível, deixar-se governar por si mesmas. O papel dos adultos se deve limitar a assistir a este governo" ( 199 |, p.225, tradução nossa). Para a autora, é papel da educação, portanto dos adultos, simultaneamente, introduzir a criança no mundo, de modo ordenado e progressivo, e protegê-la das vicissitudes deste, para preservar seu poder de inová-lo. "A linha que separa as crianças dos adultos deveria significar que não se pode nem educar os adultos, nem tratar as crianças como adultos ( 1991 , p.252).

Talvez mais radical que a posição sustentada por Arendt tenha sido o questionamento de Onora O'Neill ( 1988) - "Children's rights and children's lives" - sobre a própria adequação política de se adotar a retórica do direito em prol das crianças (mesmo reconhecendo o empoderamento que a retórica do direito propicia a "grupos sociais oprimidos"), na medida em que "as crianças mais novas são completa e inevitavelmente dependentes daqueles que têm o poder sobre suas vidas". Para a autora, tal dependência da criança (ou do

9. Disponível em: http://plato.stanford.edu/entries, rights-children/; acesso em: 12 jul. 2010. 
filho?) não é produzida artificialmente, tampouco pode cessar por "mudanças sociais ou políticas" (| 988, p.46|). Além disso, as crianças não são um grupo a ser emancipado como outras minorias porque esta condição não constitui um status na vida das pessoas permanentemente associado à opressão e discriminação (O’Neill, 1988). Nesse sentido, continua sua argumentação, os direitos fundamentais das crianças - sua educação e proteção - não teriam o melhor apoio na retórica dos direitos, mas, sim, no princípio das obrigações. A autora reverte, pois, a perspectiva de análise, passando do foco no receptor (no caso, a criança sujeito de direitos) para o do agente das obrigações (no caso os adultos que se relacionam com as crianças, nomeadamente pais e professores).

Da perspectiva de O'Neill, temos obrigações morais que podem não estar relacionadas a obrigações acionadas pelos direitos. Com respeito às crianças (filhos?), como adultos temos o dever de promover-lhes o bem-estar. Daí não se pode concluir que elas (eles?) tenham direitos contra nós (adultos? pais? $)^{10}$. A promulgação da Convenção reacendeu e atualizou essas questões, uma vez que buscou conciliar as duas correntes, para alguns, antagônicas.

\section{A CONVENÇÃO E SEU CONTEXTO}

O projeto original da Convenção Internacional sobre os Direitos da Criança foi formalmente apresentado no começo de 1978, pelo governo polonês, à Comissão de Direitos Humanos da ONU, em homenagem a Janusz Korczak (Cantwell, 1992). A previsão era que a Convenção fosse aprovada ao final de 1979, como um marco do Ano Internacional da Criança, que já havia mobilizado a sociedade internacional em prol de uma agenda para a infância (Mariano, 20l0).

$\mathrm{Na}$ medida em que somente um amplo consenso possibilitaria uma aprovação em tempo tão exíguo, o projeto original guardava bastante semelhança com a Declaração de 1959. A proposta inicial, encaminhada pelo Secretário- Geral das Nações Unidas à apreciação dos países e organizações intergovernamentais - OIGs -, recebeu muitas críticas, especialmente dos países ocidentais

10. O'Neill filia-se à corrente teórica da ética dos cuidados que foi apropriada, também, por teóricas feministas da diferença, como Gilligan, entre outras (ver Montenegro, 200 I). 
industrializados (Pilotti, 2000, p.43), referentes à sua linguagem imprecisa, a omissões em relação a uma série de direitos e a sua implementação, item fundamental em tratado internacional.

Ante a ausência de respaldo à proposta inicial, a Comissão dos Direitos Humanos decidiu criar um Grupo de Trabalho - GT -, de composição ilimitada, para apreciar um segundo projeto de Convenção, também apresentado pelo governo polonês. O GT reuniu-se uma vez por ano entre 1980 e 1987 (em duas ocasiões em 1988), visando a que a Convenção pudesse ser adotada em 1989. A Convenção foi aprovada na Comissão de Direitos Humanos, no Conselho Econômico e Social - Ecosoc - e na Assembleia Geral da ONU.

Relatos sobre o desenrolar dos trabalhos do GT permitem compreender, pelo menos em parte, as tensões que o texto carrega: um viés ocidental em documento internacional; a adoção simultânea de direitos de proteção e de liberdades".

Participaram das sessões do GT principalmente os Estados e as organizações internacionais não governamentais - Oings -, tendo sido reduzida a participação das OIGs, inclusive do Fundo das Nações Unidas para a Infância Unicef. A participação das Oings foi formal, ativa e crescente na preparação e elaboração da Convenção. Tendo considerado muito limitada sua participação inicial no GT, as Oings criaram, em 1983, um grupo ad hoc que, reunindo-se a cada dois anos, analisava as propostas apresentadas pelos países e elaborava sugestões de artigos. Embora numerosas Oings tenham participado das discussões, três delas tiveram atuação mais ativa: Defense for Children International, Bureau International Catholique de l'Enfance e Save the Children, especialmente suas filiais da Suécia e Grã-Bretanha. Essas organizações já dispunham de representações na América Latina e Caribe, as quais constituíram grupos nacionais de apoio, encarregados de difundir o conteúdo das discussões da Convenção (Pilotti, 2000). O trabalho das Oings, conforme Pilotti (2000), se concentrou, sobretudo, na inclusão de um conjunto de direitos de proteção especial, bem como na participação da sociedade civil na implementação da

I I. O relato sobre o desenrolar dos trabalhos da Convenção apoiou-se nas seguintes fontes: Cantwell (1992), Detrick (1992), Hammarberg (1990), Gonçalves (1989), Pilotti (2000), Prince-Cohen (1996). 
Convenção e seu monitoramento. Pelo menos 13 artigos, ou parágrafos substantivos, foram incluídos devido à articulação das Oings ${ }^{12}$.

A participação das OIGs aumentou somente durante a última sessão, correspondente à "segunda leitura" do texto final da Convenção. Conforme contabiliza Pilotti (2000), o Unicef e a Organização Internacional do Trabalho OIT - estiveram presentes em oito sessões; o Alto Comissariado das Nações Unidas para Refugiados - Acnur -, em cinco; a Organização das Nações Unidas para a Educação, a Ciência e a Cultura - Unesco -, a Organização Mundial da Saúde - OMS - e a Liga dos Estados Árabes, somente na última; e a Organização dos Estados Americanos - OEA - assistiu às últimas sessões.

Os Estados tiveram uma participação diferenciada conforme as regiões geopolíticas, com predomínio dos países ocidentais industrializados e reduzida participação dos países africanos (Tab. I).

TABELA I

NÚMERO DE ESTADOS PARTICIPANTES NAS SESSÕES DO GRUPO DE TRABALHO ENCARREGADO DA REDAÇÃO DA CONVENÇÃO SOBRE OS DIREITOS DA CRIANÇA ( $198 \mid *$ - 1988)

\begin{tabular}{l|c|c|c|c|c|c|c|c|c}
\hline Região/Ano & 1981 & 1982 & 1983 & 1984 & 1985 & 1986 & 1987 & 1988 & $\begin{array}{c}2 \mathrm{a} \\
\text { Leit./88 }\end{array}$ \\
\hline $\begin{array}{l}\text { Ocidente*** } \\
\text { Ásia/Or. }\end{array}$ & 14 & 13 & 15 & 14 & 18 & 16 & 17 & 18 & 22 \\
$\begin{array}{l}\text { Med. } \\
\text { América }\end{array}$ & 3 & 4 & 7 & 5 & 9 & 6 & 6 & 7 & 10 \\
Latina & 5 & 6 & 4 & 4 & 6 & 5 & 5 & 6 & 8 \\
$\begin{array}{l}\text { Europa } \\
\text { Oriental }\end{array}$ & 2 & 1 & 3 & 1 & 7 & 4 & 3 & 7 & 9 \\
África & 27 & 28 & 35 & 28 & 47 & 37 & 40 & 48 & 65 \\
\hline Total & & & & & & & 10 \\
\hline
\end{tabular}

* Não se dispõe de dados anteriores a 1981.

*** Inclui: Europa Ocidental, Estados Unidos da América, Canadá, Austrália e Nova Zelândia. Fonte: Pilotti (apud Detrick, 1992, p.644-657).

12. São eles: direitos referentes à separação da criança dos pais (art. 9), saúde (art. 24), educação (arts. 28, 29), cultura e religião (art. 30), exploração sexual (art. 34), sequestro, tráfico e venda de crianças (art. 35), tortura e pena capital (art. 37), conflito armado (art. 38), recuperação física, psicológica e reintegração social (art. 39), disposições mais favoráveis (art. 4I), difusão dos princípios e disposições da Convenção (art. 42), informes dos Estados-Partes (art. 44). 
Em se tratando da elaboração de um tratado de caráter mundial sobre os direitos da criança, era já esperada uma arena de negociações bastante tensa e conflituosa em decorrência dos embates políticos entre os Estados com diferentes interesses, desigual acesso a recursos e poder e, em especial, ante a diversidade de concepções de infância e de direitos da criança. Além da multiplicidade de atores, da diversidade de suas agendas, da duração dos trabalhos, o contexto da Guerra Fria ampliou a complexidade e duração das negociações. Conforme Marília Sardenberg Zelner Gonçalves (1989), diplomata da delegação do Brasil para os Direitos Humanos que participou dos trabalhos da Convenção, tal complexidade explicaria a incorporação de dispositivos relativamente fracos, em decorrência de tentativas de conciliação de posições "quase" divergentes.

O embate Leste-Oeste ultrapassaria os limites do GT relativo à Convenção sobre os Direitos da Criança, pois, ao mesmo tempo, a Comissão dos Direitos Humanos da ONU havia organizado outro GT, de iniciativa ocidental, cujo foco era a elaboração de uma Convenção contra a tortura. Conforme relato de Cantwell (1992, p.23), uma proposta "perdida" em um dos GTs por um bloco ricocheteava no outro GT, acirrando as rivalidades.

A arena de negociações da Convenção foi então atravessada por embates geopolíticos, nos quais a defesa da criança se tornou instrumento de disputas, principalmente no início dos trabalhos, quando os direitos humanos faziam parte da confrontação política entre os países do Leste e Oeste. Tal confronto ocorreu, em especial, na disputa entre os tipos de direitos que teriam maior peso na Convenção: os países do Leste "defendiam a primazia dos direitos econômicos e sociais, enquanto certos países ocidentais, particularmente os Estados Unidos EUA -, somente reconheciam como direitos humanos legítimos os de caráter civil e político" (Pilotti, 2000, p.43). Assim, em contraposição à preponderância de direitos sociais no projeto polonês, os EUA propuseram a inclusão da maioria dos artigos relacionados a direitos civis e políticos às crianças - liberdade de expressão; liberdade de pensamento, consciência e religião; liberdade de associação e reunião e direito à privacidade -, bem como participaram ativamente na formulação do artigo referente ao direito de acesso à informação' ${ }^{3}$.

13. Susan Kilbourne (apud Pilotti, 2000, p.44) informa que foram exatamente os artigos propostos pelos EUA no GT aqueles que geraram, posteriormente, maior oposição naquele país para ratificação da Convenção. 
Já o artigo referente à liberdade de opinião foi elaborado, principalmente, pelos representantes dos EUA, Canadá, Austrália e Dinamarca (Pilotti, 2000, p.44).

A tensão foi amenizada somente na segunda metade dos anos 1980 , quando mudanças políticas nos países do Leste Europeu os conduziram a uma aproximação das posições ocidentais nos fóruns internacionais. Tal distensão, por sua vez,

... permitiu às nações da Europa Ocidental assumir posturas mais independentes dos alinhamentos da política exterior dos Estados Unidos, o que se traduziu, por exemplo, em um apoio muito mais decidido aos direitos sociais contidos no projeto da Convenção, uma vez que se tratava de um componente central do Estado de bem-estar de inspiração social democrata. (Pilotti, 2000, p.44)

A atuação mais relevante latino-americana - representada principalmente por Argentina, Brasil, Cuba, Peru e Venezuela - foi sua "contundente" oposição às disposições sobre a adoção internacional proposta pelos países ocidentais industrializados, aliando-se, nessa questão, aos representantes dos países islâmicos, contrários à adoção por motivos religiosos (Pilotti, 2000, p.45). Gonçalves (1989) pondera que, se a atuação do Brasil pode ser considerada discreta, ela foi constante, pois houve presença de representantes brasileiros em todas as sessões a partir de 1981.

Ao final da aprovação da Convenção, o Unicef assumiu uma posição de liderança nas fases de ratificação e implementação. As Oings, por seu turno, passaram a focalizar sua ação junto às OIGs, bem como concentraram sua atenção em alguns direitos de proteção, tais como a exploração sexual de crianças, a utilização de crianças como soldados e o "trabalho infantil" (Pilotti, 2000, p.49). Todos temas midiáticos.

Até o momento, 193 países ratificaram a Convenção ${ }^{14}$. Além de ser 0 instrumento de direitos humanos mais ratificado em escala mundial $^{15}$, a grande maioria das ratificações ocorreu nos primeiros 10 anos após sua aprovação, o que não acontecera com outros tratados interna-

14. Disponível em: http://treaties.un.org/Pages/NiewDetails.aspx?src =TREATY\&mtdsg_no=IV- I I \&chapter=4\&lang=fr; acesso em: 6 mar. 2010.

I5. Disponível em: http://www.unicef.org/brazil/pt/resources_10 I20.htm; acesso em: jun. 2010. 
cionais. Somente os EUA e a Somália não procederam à ratificação da Convenção' ${ }^{16}$.

A Convenção dispôs sobre a criação de um órgão de vigilância, o Comitê de Direitos da Criança das Nações Unidas. É composto por experts independentes indicados pelos países que ratificaram a Convenção. $\bigcirc$ Comitê avalia, periodicamente, a aplicação da Convenção a partir de relatórios enviados pelos países. Pelo regulamento provisório, o Comitê, em periodicidade regular, dedica um dia de seu trabalho ao debate de um tema específico dos direitos da criança, por merecer maior esclarecimento ou atenção. Até 2004 (Fundación Bernard van Leer, 2007), haviam sido realizados debates gerais sobre os temas: exploração econômica da criança; direitos da criança e papel da família; direitos da menina; administração da justiça juvenil; direitos das crianças com necessidades especiais; HIV/Aids e o direito das crianças; violência contra a criança; realização dos direitos da criança na primeira infância. Este último tema foi selecionado por se considerar que a criança pequena, o bebê, estava sendo negligenciada na implementação da Convenção. Tal como problematizamos os novos paradigmas nos estudos da infância, a criança da Convenção também tem uma idade privilegiada que não é a pequena infância.

O Brasil ratificou a Convenção em 1990 e o governo brasileiro apresentou seu primeiro relatório ao Comitê de Direitos da Criança da ONU em 2003, portanto, com II anos de atraso no cronograma de monitoramento da Convenção. A Associação Nacional dos Centros de Defesa dos Direitos da Criança e do Adolescente - Anced - e o Fórum Nacional dos Direitos da Criança e do Adolescente apresentaram, na ocasião, um Relatório Alternativo da sociedade civil sobre Direitos da Criança no Brasil. O Comitê de Direitos da Criança apresentou 76 recomendações, sendo uma delas a de que o Brasil entregasse o próximo relatório até outubro de 2007. Não há informações oficiais até o

16. A Somália enfrenta problemas referentes à sua própria constituição como Estado nacional. Um dos principais motivos pelo qual os EUA apenas assinaram a Convenção, mas não ratificaram, decorre do teor do art. 37으, alínea a, referente à proibição da cominação de pena de morte e prisão perpétua a menores de 18 anos, o que se revelava incompatível com o direito interno norte-americano (Monteiro, 2006). Outros países, embora tenham ratificado a Convenção, mantiveram uma posição de reserva, sobretudo os muçulmanos, e recusaram atribuir validade jurídica a alguns artigos, nomeadamente ao de n. 14, que reconhece à criança o direito à liberdade religiosa, pois incorpora um valor incompatível com os propósitos culturais e religiosos dessas nações (Monteiro, 2006, p. I 54). 
momento acerca da apresentação desse segundo relatório ${ }^{17}$. Porém, a Anced elaborou, em março de 2009, em caráter preliminar, o 2ำ Relatório Alternativo dos Direitos da Criança.

\section{TENSÃO ENTRE DIREITOS ESPECIAIS E DIREITOS DE LIBERDADE}

Proclamada dia 20 de novembro de 1989, a Convenção tem sido considerada "o culminar de todo um processo de reconhecimento da infância e de seus direitos (Monteiro, 2006, p. 147). Tem caráter mandatório (art. 4ㅇ), contém maior número de artigos do que a relação à Declaração de 1959 (59 artigos) que contemplam, na linguagem dos direitos humanos: direitos civis e políticos; econômicos, sociais e culturais; direitos especiais (proteção).

Cabe lembrar que os direitos civis são aqueles necessários para garantir a liberdade individual e abarcam liberdades de: expressão, opinião, consciência e religião, associação, reunião pacífica e direito ao respeito à vida privada. São também conhecidos como direitos negativos, pois asseguram a proteção dos indivíduos diante de abusos que o Estado possa cometer. Nesse sentido, a Convenção, ao conferir um estatuto jurídico à criança, abre-Ihe a possibilidade de pleitear sem ser representada por seu tutor legal, significando o seu egresso da tutela para ser um sujeito de direitos (Brougère, $s / d$ ).

A maior particularidade da Convenção reside em que, ao lado dos direitos de liberdade, reconhece os direitos de proteção, ou denominados passivos, ou ainda, "direitos-créditos", conforme Renaut (2002). Se os direitos de liberdade e participação são reconhecidos à criança devido à sua identidade com o "homem", os direitos de proteção são devidos em razão da especificidade de ser criança. Assim, para vários analistas, aqui estaria posta uma de suas incongruências internas: a coexistência entre os direitos de proteção e os de liberdade ${ }^{18}$.

17. No Brasil, a elaboração do Relatório ao Comitê dos Direitos da Criança está a cargo da Subsecretaria de Promoção dos Direitos da Criança e do Adolescente - SPDCA -, órgão que substituiu o Departamento da Criança e do Adolescente - DCA.

18. No contexto anglo-saxônico, o debate tem ocorrido entre duas teorias antagônicas no campo da Filosofia do Direito: a teoria da capacidade e a teoria do interesse. Apesar de importante, esse debate não será tratado neste texto. Remetemos ao estudo de Campbell (1992). 
QUADRO I

SÍNTESE DOS DIREITOS DA CRIANÇA ESTABELECIDOS NA CONVENÇÃO

\begin{tabular}{|c|c|c|}
\hline Direitos civis e políticos & $\begin{array}{l}\text { Direitos econômicos, } \\
\text { sociais e culturais }\end{array}$ & Direitos especiais (proteção) \\
\hline $\begin{array}{l}\text { Registro, nome, nacionalidade, } \\
\text { conhecer os pais. } \\
\text { Expressão e acesso à } \\
\text { informação. } \\
\text { Liberdade de pensamento, } \\
\text { consciência e crença. } \\
\\
\text { Liberdade de associação. } \\
\text { Proteção da privacidade. }\end{array}$ & $\begin{array}{l}\text { Vida, sobrevivência e } \\
\text { desenvolvimento. } \\
\text { Saúde. } \\
\text { Previdência social. } \\
\text { Educação fundamental } \\
\text { (ensino primário obrigatório e } \\
\text { gratuito). } \\
\text { Nível de vida adequado ao } \\
\text { desenvolvimento integral. } \\
\text { Lazer, recreação e atividades } \\
\text { culturais. } \\
\text { Crianças de comunidades } \\
\text { minoritárias: direito de viver } \\
\text { conforme a própria cultura. }\end{array}$ & $\begin{array}{l}\text { Proteção contra abuso e } \\
\text { negligência. } \\
\text { Proteção especial e assistência } \\
\text { para a criança refugiada. } \\
\text { Educação e treinamento } \\
\text { especiais para crianças } \\
\text { portadoras de deficiência. } \\
\text { Proteção contra utilização pelo } \\
\text { tráfico de drogas, exploração } \\
\text { sexual, venda, tráfico e } \\
\text { sequestro. } \\
\text { Proteção em situação de } \\
\text { conflito armado e reabilitação } \\
\text { de vítimas desses conflitos. } \\
\text { Proteção contra trabalho } \\
\text { prejudicial à saúde e ao } \\
\text { desenvolvimento integral. } \\
\text { Proteção contra uso de drogas. } \\
\text { Garantias ao direito ao devido } \\
\text { processo legal, no caso de } \\
\text { cometimento de ato infracional. }\end{array}$ \\
\hline
\end{tabular}

Fonte: Frota (2004, p.7I).

A tensão intrínseca ao texto da Convenção tem sua complexidade ampliada perante o caráter de força de lei que passa a ter no país que opta por ratificá-la, o que pode explicar o grande número de discussões que suscitou em alguns países ao ser adotada, bem como as dificuldades em sua implementação. Na França, cultivou-se uma viva e durável polêmica sobre alguns dos equívocos que poderia acarretar essa representação contemporânea da criança como sujeito de direitos, caso não seja submetida a uma análise crítica sobre as condições para sua efetivação (Renaut, 2002) $)^{19}$.

19. A França ratificou a Convenção, porém não lhe concedeu validade interna em termos jurídicos, o que a limita à posição de documento de referência (Monteiro, 2006). Dekeuwer-Défossez (2009) informa que a França ratificou-a sob reserva ao art. 6, que proclama o direito à vida desde a concepção, o que contraria a legislação francesa referente à interrupção voluntária da gravidez. 
Assim, o filósofo Alain Finkielkraut, durante um debate organizado pela revista Autrement, afirmou que a Convenção não significava um progresso e que "prosseguir simultaneamente com esses dois princípios contraditórios conduz a tornar a proteção da criança muito mais difícil, sob o pretexto de que, por não sei qual miragem histórica, o jovem de hoje cessaria de ser influenciável" pois, "a partir do momento em que ele é considerado sujeito de direitos, ele é considerado como estando consciente de seus interesses e, por consequência, desaparece o possível manipulador" (Finkielkraut, I99।, p. 175). Ou seja, o filósofo pressupõe que a proclamação dos direitos de liberdade para a criança poderia constituir um obstáculo à consideração de sua vulnerabilidade, fragilidade e irresponsabilidade e, assim, ameaçaria o direito de a criança ser diferente dos adultos. Por consequência, cairia por terra a razão de conferir-Ihe proteção especial (Renaut, 2002).

A socióloga Irène Théry (1996, p.343) também compartilha dessa visão e critica o texto da Convenção: contesta, especificamente, os direitos à liberdade de opinião (art. 12), à liberdade de expressão (art. 13), à liberdade de pensamento, de consciência e de religião (art. 14), à liberdade de associação (art. 15), pois "são direitos que implicam a capacidade jurídica, ou seja, a responsabilidade". Para Théry, a concepção de proteção especial adotada pela Convenção remanesce da tradição da Filosofia que prevaleceu nas Declarações de 1924 e 1959. Essa tradição é elucidada pela autora da seguinte forma:

$\mathrm{Na}$ tradição de proteção, a Filosofia adverte que os direitos do homem - em particular em Kant e Condorcet -, a ideia fundamental é a da educação, da instrução. Se o homem é por essência um ser livre, ele somente assim se torna realmente realizando o processo educacional que o faz alcançar a autonomia e a responsabilidade [...] Neste sentido, os direitos da criança são aqueles de seres humanos particularmente vulneráveis, porque ainda não são autônomos. A incapacidade legal nada mais é que o direito a uma certa irresponsabilidade, quer dizer, a não ser submetido ao dever que implica a capacidade. (Théry, 1996, p.34l-342)

Théry (1996) considera que a campanha entusiástica sobre os novos direitos da criança, orquestrada em torno do processo de ratificação da Convenção na França, dificultou um debate prudente sobre as consequências de 
quando a proteção deixa de ser um direito primeiro da criança, sobretudo nas questões relativas à autoridade parental, às implicações da recomendação da oitiva das crianças nos assuntos de seu interesse e à possibilidade de a criança recorrer à justiça contra seus pais, ou constituir advogado para defender seus interesses em litígios familiares. Questões instigantes emergem dessas situações: crianças e adolescentes deveriam suportar o ônus de serem envolvidos no processo de separação encetado pelos pais? O que significa autonomia da palavra dos filhos no divórcio de seus pais? Podemos realmente acreditar que eles não seriam instrumentalizados pelos pais?

Ao mesmo tempo em que reconhece que no debate proteção versus autonomia não pretenda decidir qual das posições é verdadeira, Renaut (2002) pondera que ambas padecem de um "singular erro sobre a definição da cidadania". Para o autor, protecionistas e liberacionistas partem da certeza de que a Convenção atribuiria à criança os direitos de cidadão:

... a cidadania não está de modo algum contida no próprio fato de reconhecer ao indivíduo humano (nem que seja uma criança) garantias jurídicas [...] dentro da lógica da teoria do direito democrático, é perfeitamente possível beneficiar dos direitos do homem sem ser cidadão - o que é caso do estrangeiro; ora, não será, precisamente, também este estatuto que foi retido em relação à criança em 1989? Neste sentido, os direitos-liberdades reconhecidos aos menores na Convenção [...] dependem, no essencial, não da cidadania, mas da humanidade. Assim sendo, a questão não é, de modo algum, saber se a Convenção esteve certa ou errada em reconhecer à criança direitos que the impõem a responsabilidade do cidadão, visto que, contrariamente ao que se julgou até agora de um lado e de outro, não procedeu a este reconhecimento. (Renaut, 2002, p.312-313)

No Brasil, Rita de Cássia Marchi (2009) propõe uma releitura da discussão efetuada por Renaut (2002) e oferece "uma pista" para a compreensão dessa tensão focalizando-a pelo prisma da "radicalização do processo histórico da individualização de crianças". Para a autora, às voltas com o debate sobre a "crise social da infância", estaríamos diante de modos contrastados de lidar historicamente com a infância" e que "vêm se ombreando historicamente": de um lado, a "proteção e homogeneização das diferenças individuais" e, 
de outro, a "liberação e individualização". Para Marchi (2009), o modo de proteção/homogeneização, apesar de dominante por longo tempo, não teria eliminado o modo de "liberação/individualização" uma vez que este "manteve-se presente mais evidentemente na individualização da criança" fora da norma ("delinquente", "não socializada"). A novidade é que, na atualidade, o modo liberdade/individualização estaria "aflorando também entre a infância normalizada", o que seria "visto como colocando a própria ideia de infância em risco" (Marchi, 2009). Além de provocadora, instigando um debate (pois sua pedra de toque implica a aceitação da noção de crianças sem infância), discussões como a de Marchi (2009) sobre a tensão entre direitos de liberdade e de proteção constituem uma raridade no Brasil.

\section{DEBATE SOBRE A CONVENÇÃO NO BRASIL}

Um primeiro aspecto notável é o fato de a Convenção ter suscitado um pequeno, e apenas recente, debate no Brasil, seja ele acadêmico ou midiático. Três exemplos: a análise exaustiva do jornal Folha de S.Paulo, entre 1985 e 2006, permitiu a localização de apenas dois artigos sobre a Convenção, sendo um deles de autoria do sociólogo francês Alain Touraine (Mariano, 2010). A base de dados Scielo não dispõe do descritor, portanto, nenhum artigo foi localizado. A análise, por sua vez, também sistemática, do banco de teses da Coordenação de Aperfeiçoamento de Pessoal de Ensino Superior - Capes permitiu que localizássemos, sob o assunto "Convenção Internacional sobre os Direitos da Criança”, apenas 28 dissertações de mestrado e sete teses de doutorado, no período 1989-2009, produzidas em ritmo bissexto. Além disso, cabe destacar, também, a restrita amplitude dos temas que vêm sendo tratados: no levantamento mencionado, os temas prevalentes nos resumos são a adoção internacional $(25,7 \%)$ e a privação de liberdade (17,1\%).

Segundo Méndez (200I), a América Latina e o Caribe foram pioneiros no processo mundial de ratificação da Convenção, tendo muitos países a transformado em lei nacional mediante um trâmite de aprovação parlamentar. A aprovação e difusão da Convenção na região coincidiu com o retorno à democracia em vários países (Méndez, 200l), o que permite sugerir que a linguagem progressista dos novos direitos da criança se ajustava e impulsionava a reconstrução da democracia na região, o que pode ter contribuído para 
franquear, sem maior debate ou contextualização, as céleres ratificações da Convenção na América Latina,inclusive no Brasil.

Dois meses antes de sancionar o ECA, em maio de 1990, o então Presidente Fernando Collor de Mello anunciava, em 3।/5/I989, a criação do Ministério da Criança, concomitantemente ao encaminhamento, ao Congresso Nacional, da proposta de ratificação da Convenção Internacional sobre os Direitos da Criança. Seu discurso naquela ocasião:

... a partir de hoje, deste momento, a qualidade de vida de nossas crianças será preocupação central e objetivo maior da ação do Governo [...] Não podemos ser o Brasil dos "pixotes" [...]. Temos o dever de reverter essa situação; de garantir alimentação e saúde para as nossas crianças. Temos de tirá-las das ruas e dos desvios da marginalidade; de encaminhá-las à escola motivando-as para o estudo. Temos de levá-las de volta ao seio da família, ao convívio e guarda de pais capazes de dar-Ihes sustento, afeto e amor; de fazer prevalecer o sentido da paternidade responsável. Temos de recuperar de uma vez por todas a família brasileira. (Mello, apud Costa et al., 1990, p. I6)

Collor prenunciava o tom: não obstante a CF/I988 e o ECA terem incorporado concepções e dispositivos da Convenção - acolhendo, portanto, as tensões decorrentes do reconhecimento da condição de sujeitos de direitos a crianças e adolescentes -, a divulgação dos novos direitos da criança no Brasil centrou-se em sua utilidade para combater a doutrina da "situação irregular" que orientara o Código de Menores de 1979. Com efeito, desde o processo Constituinte e, mais intensamente, durante a elaboração e aprovação ao ECA, a tônica do debate brasileiro foi contrapor a doutrina de proteção integral à criança e ao adolescente à antiga doutrina de situação irregular (Rosemberg, 2008).

Certamente as condições econômicas, sociais e políticas que nos diferenciam do hemisfério norte, particularmente tendo em conta a crise econômica e as políticas de ajuste na década de 1980 e suas graves implicações na vida de crianças e adolescentes pobres (Chahad, Cervini, 1988), podem explicar as particularidades do debate brasileiro sobre os direitos de crianças e adolescentes. De fato, expressivo percentual das crianças brasileiras viveu, e ainda vive, abaixo da linha da pobreza (Ribeiro, Saboia, 1993; Brasil, 2007). Conforme 
Marchi (2009), "no Brasil, trata-se ainda de garantir igualdade entre crianças. A igualdade da criança na relação com o adulto enfatizada por Renaut - ou seja, enquanto um ser livre - resta, por motivos macroestruturais, em segundo plano na sociedade brasileira".

Seria isto, porém, justificativa suficiente para que a produção acadêmica também restringisse sua amplitude temática, teórica e metodológica? Com efeito, no Estado da arte sobre juventude na pós-graduação brasileira (Sposito, 2009) - que inclui também estudos que adotam o descritor adolescente/adolescência -, Sposito, De Tommasi e Moreno (2009) identificam, além da relevância dada ao tema "juventude em exclusão social", na produção discente na pós-graduação brasileira (Educação, Serviço Social e Sociologia), o predomínio do subtema "adolescentes em conflito com a lei" (p. I28). Os autores ressaltam, a nosso ver, com justeza, "a força simbólica e política do ECA, que, além de um instrumento jurídico, compôs um quadro de referência normativo para a análise das realidades investigadas". Assinalam que muitos pesquisadores estão envolvidos profissional e politicamente com o tema, o que redunda no fato de que "muitas pesquisas são tensionadas pelos anseios dos pesquisadores em encontrar respostas e propor alternativas" e terminam por sugerir um "adensamento teórico e metodológico na formação dos alunos de pós-graduação".

A despeito das carências apontadas, localizamos alguns poucos autores que, se não adentram o debate sobre a tensão entre direitos de liberdade e de proteção, pelo menos tangenciam a questão ou explicitam um posicionamento.

Os direitos à liberdade, ao respeito e à dignidade prescritos pelo ECA (cap.2) foram comentados por Monaco (2005, p. I 64), que, ao ressignificá-los, assinala sua importância no desenvolvimento da personalidade de crianças e adolescentes "com vistas a sua plena conformação e de acordo com seu interesse superior". Entende que crianças e adolescentes devem sofrer "restrições nessa liberdade justamente em função desse mesmo interesse superior flexionado para o pleno desenvolvimento de suas características humanas", portanto, reserva direitos à liberdade para uma etapa posterior da vida. Nesse sentido, parece-nos adotar uma concepção de infância como ser inacabado e relações de idade assimétricas. Exatamente essa assimetria é questionada por Fajardo (1999), mas, desta feita, para questionar o conceito de proteção integral, quando lembra que "proteção é uma estratégia de tratamento da infância desamparada, que inclui aspectos repressivos e preventivos" e que 
pressupõe uma assimetria entre protetor e protegido. Fajardo (1999) destaca que essa assimetria é reforçada pela "ideologia da incapacidade" infantil, que "se expressa, às vezes, por meio do conceito de discernimento associado à idade, como um critério para restrição de direitos", tangenciando o debate entre as teorias do direito como vontade ou interesse.

"Da criança-cidadã ao fim da infância" (Brayner, 200 I) é um texto brasileiro que se posiciona frontalmente contrário aos direitos de liberdade. Reportando-se à criança no universo escolar, o autor discute a "recente insistência sobre a necessidade dos 'direitos da criança' que tenta tratá-las como autônomas ou, ainda, como 'cidadãos-alunos'”. Brayner (200 I, p.208) declaradamente se contrapõe às ideias de Jonh Holt, e, para afirmar a impropriedade da "euforia do princípio igualitário" nas relações adulto-criança, bem como dos perigos de manipulação da criança, ancora-se no pressuposto de que, "na relação intergeracional, não estamos diante de 'iguais': a autonomia do cidadão (adulto) não coaduna com a heteronomia infligida à infância".

Uma breve tomada de posição quanto à adequação do uso do conceito cidadão, para as crianças, pode ser encontrada no livro de Alba Zaluar ( 1994 , p.23) Cidadãos não vão ao paraíso. Para a autora, pelo fato de crianças estarem em processo de socialização, "devem ser preparadas para assumir direitos e deveres na vida adulta, o que lhes retira responsabilidades jurídicas, assim como alguns direitos civis e políticos".

tema da cidadania, principalmente a partir das contribuições de Marshall, foi mote para outros dois trabalhos brasileiros que tratam da tensão entre direitos de liberdade e de proteção: apenas mencionado em Pinheiro (2006, p.96), em sua importante pesquisa sobre a representação social da infância apreendida na análise do processo constituinte; foco central na dissertação de Monteiro (2006a). Esta autora parte da crítica à concepção restrita de cidadania em Marshall, que se mostra excludente para crianças e adolescentes ao concebê-los como futuros adultos cidadãos. Busca, então, para além do campo dos direitos, vislumbrar formas de reconhecimento social de crianças e adolescentes como atores competentes e participativos na sociedade contemporânea. Localiza a cultura de consumo, entendida como uma nova forma de ação coletiva, de exercício da cidadania, "como um terreno privilegiado onde crianças e jovens por meio de manifestações culturais e de 
consumo aparecem como atores relevantes na sociedade", com poder de introduzir valores, símbolos e significados (Monteiro, 2006a, p. 108).

Duas autoras de destaque no campo da Psicologia - Lucia Rabello de Castro (200 I) e Solange Jobim e Souza (2008) - questionam a relação tutelar de adultos sobre crianças, particularmente aquela que se depreende do enfoque tradicional da Psicologia do Desenvolvimento. Para Castro (200 I , p.27), a afirmação da criança como sujeito de direitos implica superar a concepção de que se trata de alguém "ainda não dotado de suas plenas capacidades". Para a autora, apoiada na Teoria da Ação (Hannah Arendt e Max Weber), crianças e adolescentes poderão ser considerados sujeitos de direitos apenas quando tiverem suas ações concebidas como verdadeiramente válidas. Souza, por sua vez, não sugere solução, mas evoca como desafio contemporâneo:

...equacionar a tensão que se instala entre conceder maior autonomia à infância, direito de voz e participação política [...] e o risco de que esta prática possa favorecer uma certa omissão dos adultos e das instituições em construir junto com as crianças metas que garantam a proteção dos direitos das crianças. (Souza, 2008, s/p.)

No plano acadêmico, algumas poucas pesquisas têm centrado o foco na tensão entre direitos de liberdade e de proteção na análise das recentes campanhas orquestradas pela OIT e abraçadas pelo Brasil, referentes à "erradicação do trabalho infantil" (Freitas, 2004; Prado, 2009).

No plano jurídico, ocorre também um debate quanto aos direitos sexuais e reprodutivos de adolescentes. Alguns analistas têm ponderado que a negação aos adolescentes da autodeterminação reprodutiva e sexual pode significar, também, sua negação como sujeitos de direitos. Dessa maneira, estaria prevalecendo uma perspectiva tutelar em relação aos adolescentes, ao se lhes exigir, por exemplo, o acompanhamento por um "responsável" para ter acesso aos serviços de saúde (Ventura, 2005; Pirotta, Pirotta, 2005). Pirotta e Pirotta (2005) assinalam que, em relação à sexualidade dos adolescentes, o ECA se posiciona apenas pela negativa, prevalecendo a preocupação de prevenir e coibir o abuso e a exploração sexual de crianças e adolescentes por adultos. Para alguns (Ventura, 2005), a exclusão da perspectiva dos direitos na discussão da sexualidade do adolescente pode acarretar a violação de vários outros 
direitos: o direito à privacidade, ao sigilo, à informação, à saúde reprodutiva e sexual, à não discriminação, ao consentimento informado. Assim, os direitos de liberdade do ECA e da Convenção têm sido evocados para sustentar a reivindicação da afirmação dos direitos sexuais e reprodutivos de adolescentes, tornando, portanto, explícita a tensão entre eles e os de proteção.

Outra frente aberta na produção brasileira se refere ao direito de participação de crianças e adolescentes na vida social. De um lado, notamos ênfase na pesquisa sobre a escuta de crianças (Bernardi, 2005; Cruz, Hollanda, 2004, entre outros) como um dos desdobramentos de sua liberdade de opinião e participação. De outro, um debate, particularmente na Educação, sobre significados, implicações e, para alguns, desatinos político-ideológicos do que alguns vêm denominando protagonismo infantil (Pires, 2007) ou protagonismo juvenil (Ferretti, Zibas, Tartuce, 2004; Sposito, Brenner, Moraes, 2009).

Finalmente, destacamos a calorosa discussão em torno da inquirição judicial de crianças e adolescentes como vítima ou testemunha de crimes, que adota a metodologia do "depoimento sem dano" ${ }^{20}$. Nesse caso, é o direito à diferença no tratamento dado à criança ou adolescente que ganha relevo. Os argumentos contrários ao depoimento sem dano ressaltam que o ECA, ao assegurar a condição de sujeito de direito às crianças, não aboliu sua diferença diante do adulto (Arantes, 2009). A autora evoca, justamente, o reconhecimento da tensão entre os direitos de proteção e de autonomia de crianças e adolescentes para se contrapor à mencionada proposta. Para ela, a busca pela responsabilização do agressor não deve se sobrepor às implicações decorrentes de crianças e adolescentes serem inquiridos como vítima ou testemunha para produção de provas que podem, inclusive, servir para condenar criminalmente seus pais e familiares. Nesse sentido, Arantes (2009) indaga se a proposta em tela não estaria equiparando o direito de crianças e adolescentes serem ouvidos à obrigação de testemunhar. Arantes (2009) traz assim para o debate ponderações sobre quanto um dispositivo autonomista (o direito de a criança se expressar) pode ser interpretado e institucionalizado de modo a violar o direito de crianças e adolescentes de serem protegidos. Perguntamos: protegidos contra quem ou contra o quê?

20. O Conselho Federal de Psicologia tem promovido debates sobre o "depoimento sem dano", previsto no Substitutivo do Projeto de Lei n. 4. 126/2004, que propõe alterações ao ECA. 
Este nos parece ser um dos pontos cruciais na tensão instaurada quando avançamos na atribuição do direito de crianças e adolescentes à autonomia e à voz. Ou seja: cabe-nos indagar se reconhecer as crianças como atores sociais - dotadas de competências para apreender e alterar a realidade, com algum (ou certo) grau de consciência sobre o que pensam, sentem e desejam, com capacidade para emitir opiniões e fazer escolhas - significa, também, reconhecer que devem assumir o ônus de decisões importantes ou de ser envolvidas em processos judiciais, cujo controle lhes escapa, em boa medida, porque as instituições estão erigidas e funcionam em sociedades adultocêntricas?

Portanto, para além de uma vulnerabilidade inerente a crianças e adolescentes, está implicada a tensão entre os direitos de liberdade e proteção, sua vulnerabilidade estrutural que, ademais, assume contornos diferentes para as subetapas que constituem a infância e a adolescência. Contribuímos, então, para o debate, problematizando de um lado a unicidade da categoria infância, ante a desigual visibilidade pública e de acesso a recursos sociais, políticos e econômicos, não só para os diferentes segmentos sociais, mas também para os diferentes subgrupos etários que a compõem. Destacamos, em seguida, tal como Lansdown ( 1994) e Soares (2002), a diferenciação entre vulnerabilidade inerente a essa etapa da vida e a vulnerabilidade estrutural, decorrente da posição socialmente subordinada da infância. Por tais razões, concebemos os direitos de liberdade como um ideal regulador das interações entre adultos e crianças no espaço público e na família, que devem ser interpretados à luz da posição de subordinação das infâncias, e, portanto, de sua vulnerabilidade estrutural nas sociedades contemporâneas. Porém, a concretização de direitos de liberdade para crianças e adolescentes extrapola as relações interpessoais, adentrando as instituições e os diversos setores da vida em sociedade. Direito de participação sem canais, sem transporte coletivo para circular, sem espaços para isto destinados, sem informação disponível? Assim, os direitos de liberdade da criança se veem também ressignificados pelos limites determinados pelas políticas públicas e pelos riscos reais derivados de nós adultos e das instituições que criamos, ao impingirmos à infância uma posição de subordinação. Sem uma análise consistente das relações de dominação, inclusive (e sobretudo, mas não exclusivamente) as etárias, declarações, estatutos ou convenções dos direitos das crianças podem gerar dispositivos que ampliam o poder adulto. 


\section{REFERÊNCIAS BIBLIOGRÁFICAS}

ARANTES, E. M. de M. Pensando a proteção integral: contribuições ao debate sobre as propostas de inquirição judicial de crianças e adolescentes como vítimas ou testemunhas de crimes. In: CONSELHO FEDERAL DE PSICOLOGIA. Falando sério sobre a escuta de crianças e adolescentes envolvidos em situação de violência e a rede de proteção: propostas do Conselho Federal de Psicologia. Brasília, 2009. p.79-99.

ARENDT, H. La crise de la culture: huit exercises de pensée politique. Paris: Idées, 199I. ARIÈS, P. L'Enfant et la vie familiale sous l'ancien régime. Paris: Plon, 1961.

ASSOCIAÇÃO NACIONAL DOS CENTROS DE DEFESA DA CRINAÇA E DO ADOLESCENTE; FÓRUM DOS DIREITOS DA CRIANÇA E DO ADOLESCENTE. Relatório sobre a situação dos direitos da criança e do adolescente no Brasil. Brasília: Anced, FNDCA, 2004. BECCHI, E. Le XXe siècle. In: BECCHII, E. JULIA, D. (Org.). Histoire de l'enfance en occidente, 2. Paris: Éditions du Seuil, 1998, p.358-433.

BERGER, B. M. Liberação da sexualidade infantil: experiência comunitária. In: CONSTANTINE, L.; MARTINSON, F. M. (Org.). Sexualidade infantil: novos conceitos, novas perspectivas. São Paulo: Roca, 1984.

BERNARDI, D. C. F. Concepções de infância em relatórios psicológicos judiciais. 2005. Dissertação (Mestrado em Psicologia Social) - Pontifícia Universidade Católica de São Paulo, São Paulo. BEST, J. Social problems. New York: W.W. Norton \& Company, 2008.

BOBBIO, N. A Era dos direitos. Rio de Janeiro: Campus, 1992.

BOYDEN, J. Childhood and the policy makers: a comparative perspective on the globalization of childhood. In: JAMES, A.; PROUT, A. (Ed.). Constructing and reconstructing childhood: contemporary issues in the sociological study of childhood. London: Falmer, 1997. p. 190-229.

BRASIL, Constituição Federal de 1988. Brasília, 1988. Disponível em: <http://www.alep. pr.gov.br/system/files/corpo/conl988br.pdf>. Acesso em: jun. 2010.

BRASIL. Ipea. Políticas sociais: acompanhamento e análise. Brasília, 2007.

BRAYNER, F. Da criança-cidadã ao fim da infância. Revista Educação e Sociedade, Campinas, v.23, n.76, p. 197-211, out.2001.

BROUGÈRE, G. Dépendance et autonomie. Disponível em: <www.ofaj.org/paed/texte2/ enfants/enfants.html >. Acesso em: jun.20 I0. 
BUGLIONE, S. Sujeito de direito $x$ sujeito sexual: conflitos sobre os direitos sexuais dos adolescentes. In: ADORNO, R. C. F.; ALVARENGA, A. T.; VASCONCELLOS, M. P. C. Jovens, trajetórias, masculinidades e direitos. São Paulo: Fapesp, Edusp, 2005. p.53-74.

CADERNOS DE PESQUISA. São Paulo, n.31, dez. 1979.

CAMPBELL, T. D. The rights of the minor: as person, as child, as juvenile, as future adult. In: ALSTON, P.; PARKER, S.;SYMOUR, J. (Ed.). Children, rights and the law. New York: Oxford University Press, 1992. p. I-23.

CANTWELL, N. The origins, development and significance of the United Nations Convention on the Rights of the Child. In: DETRICK, S. (Ed.). The United Nations Convention on the Rights of the Child: a guide to the "travaux preparatoires". Holanda: Martinus Nijhoff, 1992. p. 19-30.

CASTRO, L. R. Da invisibilidade à ação: crianças e jovens na construção da cultura. In: . (Org.). Crianças e jovens na construção da cultura. Rio de Janeiro: NAU, Faperj, 200 I. p. 19-46.

CHAHAD, J. P. Z.; CERVINI, R. Crise e infância no Brasil. São Paulo: Unicef, 1988.

COHEN, H. Equal rights for children. Totowa: Littlefield, Adams, 1980.

COHN, C. Antropologia da criança. Rio de Janeiro: Zahar, 2005.

COSTA, A. C. G. et al. Brasil, criança urgente. São Paulo: Columbus Cultural, 1990.

CORSARO, W. A. The Sociology of childhood. London: Pine Forge, 1997.

CRUZ, S. H. V; HOLLANDA, M. P. (Org.). Linguagem e educação da criança. Fortaleza: UFC, 2004.

DALLARI, D. A. Os Direitos da criança. In: DALLARI, D. A.; KORCZAK, J. O Direito da criança ao respeito. São Paulo: Summus, 1986. p.21-6I.

DALLARI, D. A.; KORCZAK, J. O Direito da criança ao respeito. São Paulo: Summus, 1986. DEKEUWER-DÉFOSSEZ, F. Les Droits de l'enfant. 8. ed. Paris: PUF, 2009.

DELGADO, A. C. C.; MÜLLER, F. Em busca de metodologias investigativas com as crianças e suas culturas. Cadernos de Pesquisa, São Paulo, v.35, n. 125, p. I6 |-179, maio/ago. 2005.

DETRICK, S. (Ed.). The United Nations Convention on the Rights of the Child: a guide to the "travaux preparatoires". Nederlands: Martinus Nijhoff, 1992.

FAJARDO, S. P. Retórica e realidade dos direitos da criança no Brasil, 1999. Disponível em: <http://www.abmp.org.br/textos/250l.htm>. Acesso em: ago. 2010.

FARSON, R. Birthrights: a bill of rights for children. New York: Macmillan, 1974. 
FERNANDES, F. Folclore e mudança social na cidade de São Paulo. 2.ed. Petrópolis: Vozes, 1979. As trocinhas do Bom Retiro. p. 153-258.

FERRETTI, C. J.; ZIBAS, D. M. L.; TARTUCE, G. L. B. P. Protagonismo juvenil na literatura especializada e na reforma do ensino médio. Cadernos de Pesquisa, São Paulo, v. 34, n. I 22 , p.4I I-423, 2004.

FINKIELKRAUT, A. Les Paradoxes. Autrement: le 10-13 ans, Paris, n. I23, sept. I991. (série Mutations)

FIRESTONE, S. A Dialética do sexo: um manifesto da revolução feminista. Rio de Janeiro: Labor do Brasil, 1976.

FONSECA, C.; SCHUCH, P. (Org.). Políticas de proteção à infância: um olhar antropológico. Porto Alegre: UFRGS, 2009.

FRANKLIN, B. Children's rights: an introduction. In: (Ed.). The New handbook of children's rights: comparative policy and practice. Londres, New York: Routledge, 2002. p. I-9. FREITAS, R. R. O Tema trabalho infantojuvenil na mídia: uma interpretação ideológica. 2004. Tese (Doutorado em Psicologia Social) - Pontifícia Universidade Católica de São Paulo, São Paulo.

FREITAS, M. C.; KUHLMANN JR., M. (Org.). Os Intelectuais na história da infância. São Paulo: Cortez, 2002.

FROTA, M. G. da C. Associativismo civil e participação social: desafios de âmbito local e global na implementação dos direitos da criança. 2004. Tese (Doutorado em Sociologia) - luperj, Rio de Janeiro.

FUNDACIÓN BERNARD VAN LEER. Realización de los derechos del niño en la primera infancia. La Haya, 2007. (Guía a la Observación General, n. 7)

GONÇALVES, M. Z. Intervenção nas sessões reservadas. Direitos da criança: Actas da consulta aos países de língua portuguesa sobre o projecto de Convenção relativa aos direitos da criança (Lisboa, setembro 1988). Cadernos do Centro de Estudos Judiciários, Lisboa, n. I, p.75-83, 1989.

HAMMARBERG, T. The UN Covention on the rights of the child: and how to make it work. Human Rights Quarterly, Baltimore, n. 12, p.97-105, 1990.

HARVARD EDUCATIONAL REVIEW (Ed.). The Rights of children. Cambridge: Harvard Educational Review, 1974.

HILGARTNER, S.; BOSK, C. L. The Rise and fall of social problems: a public arena model. American Journal of Sociology, Chicago, n. 94, p.53-78, jul. 1988. 
HOLT, J. Escape from childhood: the needs and rights of children. New York: E.P. Dutton, 1974. JAMES, A.; PROUT, A. Re-presenting childhood: time and transition in the study of childhood. In: JAMES, A.; PROUT, A. (Ed.). Constructing and reconstructing childhood: contemporary issues in the sociological study of childhood. London: Falmer, 2003. p.230-250.

JENKS, C. Constituindo a criança. Educação, Sociedade e Culturas, Porto, n. I7, p. I 85-2 I 6, 2002.

KORCZAK, J. Como amar uma criança. 2. ed. Lisboa: Edições 70, 1929.

. O Direito da criança ao respeito. São Paulo: Perspectiva, 1984.

. Quando eu voltar a ser criança. São Paulo: Círculo do Livro, 1987.

LAHIRE, B. L'Invention de I' "illettrisme" rhétorique publique éthique et stigmates. Paris: La Découverte, 2005.

LANSDOWN, G. Children's rights. In: MAYALL, B. (Org.). Children's childhoods: observed and experienced. New York: Falmer, 1994. p.33-44.

LIPOWETSKY, G. O Império do efêmero: a moda e seu destino nas sociedades modernas. São Paulo: Companhia das Letras, 1989.

MALLY, L. Culture of the future: the proletkult movement in revolutionary Russia. Berkeley: University of California, 1990. Disponível em: <http://content.cdlib.org/xtf/ view?doclD =ft6m3nb4b2\& brand_ucpress $>$. Acesso em: jun. 2010.

MARCHI, R. C. A Radicalização do processo histórico de individualização da criança e a "crise social" da infância. Blumenau: Universidade Regional de Blumenau, 2009.

MARIANO, C. L. S. Direitos da criança e do adolescente: os marcos legais e a mídia. 2010. Tese em elaboração (Doutorado em Psicologia Social) - Pontifícia Universidade Católica de São Paulo, São Paulo.

MENDELL, G. Pour décoloniser l'enfant: sociopsychanalise de l'autorité. Paris: Payot, 1972.

MÉNDEZ, E. G. Infância, lei e democracia: uma questão de justiça. In: MÉNDEZ, E. G.; BELOFF, M. (Org.). Infância, lei e democracia na América Latina: análise crítica do panorama legislativo no marco da Convenção Internacional dos Direitos da Criança (1990-1998). Blumenau: Edifurb, 200। . p.21-46.

MOLLO, S. Resenha. Revue Française de Pedagogie, Paris, v.20, n.20, p.7I-73, 1972.

MONACO, G. F. de C. A Proteção da criança no cenário internacional. Belo Horizonte: Del Rey, 2005. 
MONTANDON, C. Sociologia da infância: balanço dos trabalhos em língua inglesa. Cadernos de Pesquisa, São Paulo, n. I 12, p.33-60, mar. 2001 .

MONTEIRO, L. C. G. Educação e direitos da criança: perspectiva histórica e desafios pedagógicos. 2006. Dissertação (Mestrado em Educação). Universidade do Minho, Braga.

MONTEIRO, R. A. P. Do direito à participação: considerações sobre a cidadania de crianças e jovens no contemporâneo. 2006a. Dissertação (Mestrado em Psicologia) - Universidade Federal do Rio de Janeiro, Rio de Janeiro.

MONTENEGRO, T. O Cuidado e a formação moral na educação infantil. São Paulo: Educ, 200 I . MOSS, P. La Defensora de los niños y las niñas en Noruega, un hito para la infancia. Infancia en Europa, Barcelona, n. 17, p.5-7, 2009.

OLDMAN, D. Adult-child relations as class relations. In: QVORTRUP, J. (Org.). Childhood matters: social theory, practice and politics. Avebury: Aldershot, 1994. p.43-58.

O'NEILL, O. Children's rights and children's lives. Ethics, Berkeley, v.98, n.3, p.445-463, abr. 1988.

PILOTTI, F. Globalización y convención sobre los derechos del niño: el contexto del texto. Washington: OEA, 2000. (Documento da OEA)

PINHEIRO, A. A. A. Criança e adolescente no Brasil: porque o abismo entre a lei e a realidade. Fortaleza: UFC, 2006.

PIRES, S. F. S. Protagonismo infantil e promoção da cultura de paz: um estudo sociocultural construtivista. 2007. Tese (Doutorado) - Instituto de Psicologia, Universidade de Brasília, Brasília.

PIROTTA, W. R. B; PIROTTA, K. C. M. Relações de gênero e poder: os adolescentes e os direitos sexuais e reprodutivos no Estatuto da Criança e do Adolescente. In: ADORNO, R. C. F.; ALVARENGA, A. T.; VASCONCELLOS, M. P. C. Jovens, trajetórias, masculinidades e direitos. São Paulo: Fapesp, Edusp, 2005. p.75-90.

POSTMAN, N. O Desaparecimento da infância. Rio de Janeiro: Graphia, 1999.

PRADO, R. L. C. O Tema trabalho infantojuvenil em artigos acadêmicos de psicólogos(as): uma interpretação ideológica. São Paulo, 2009. Dissertação (Mestrado em Psicologia Social). Pontifícia Universidade Católica de São Paulo.

PRICE-COHEN, C. Drafting of the United Nations Convention on the Rights of the Child: Challenges and Achievements. In: VERHELLEN, E. (Ed.). Understanding Children's Rights. Ghent: University of Ghent, 1996.

PRIORE, M. História da criança no Brasil. São Paulo, Contexto, 1991. 
PROUT, A.; JAMES, A. A New paradigm for the sociology of childhood? Provenance, promise and problems. In: JAMES, A.; PROUT, A. (Orgs). Constructing and reconstructing childhood: contemporary issues in the sociological study of childhood. London: Falmer, 1990. p.7-34.

QVORTRUP, J. O Trabalho escolar infantil tem valor? A colonização das crianças pelo trabalho escolar. In: CASTRO, L. R. (Org.). Crianças e jovens na construção da cultura. Rio de Janeiro: NAU, Faperj, 200I. p. I29-152.

RENAUT, A. A Libertação das crianças: a era da criança cidadão. Lisboa: Instituto Piaget, 2002. RIBEIRO, R.; SABOIA, A. L. Crianças e adolescentes na década de 80: condições de vida e perspectivas para o terceiro milênio. In: RIZZINI, I. (Org.). A Criança no Brasil hoje: desafio para o terceiro milênio. Rio de Janeiro: Universitária Santa Úrsula, 1993.

ROSEMBERG, F. Crianças e adolescentes na sociedade brasileira e a Constituição de 1988. In: OLIVEN, R. G.; RIDENTI, M.; BRANDÃO, G. M. (Org.). A Constituição de 1988 na vida brasileira. São Paulo: Hucitec, 2008. p.296-333.

. Educação para quem? Revista Ciência e Cultura, Campinas, v.28, n. I2, p. I466147|, dez. 1976.

. Uma tragédia anunciada: a educação pré-escolar obrigatória. São Paulo: FCC, 2010. Mimeo.

ROSEMBERG, F; ANDRADE, M. Infância na mídia brasileira e ideologia. In: JACÓ-VILELA, A. M.; SATO, L. (Org.). Diálogos em Psicologia Social. Porto Alegre: Evangraf, 2007. p.257-274.

SÁNCHEZ-JANKOWSKI, M. As Gangues e a imprensa: a produção de um mito nacional. Revista Brasileira de Educação, São Paulo, n.5/6, p. I80-198, maio/dez. 1997.

SIROTA, R. Emergência de uma Sociologia da Infância: evolução do objeto e do olhar. Cadernos de Pesquisa, São Paulo, n. I 12, p.7-31, mar. 2001.

SOARES, N. F. Direitos da criança: utopia ou realidade? In: PINTO, M.; SARMENTO, J. (Org.). As Crianças: contextos e identidades. Braga: 1997. p.75- I। I.

. Os Direitos das crianças nas encruzilhadas da protecção e da participação. In: ENCONTRO NACIONAL SOBRE MAUS TRATOS, NEGLIGÊNCIA E RISCO, NA INFÂNCIA E NAADOLESCÊNCIA, I , I4- 16 nov. 2002, Maia. Disponível em: < http://cedic.iec.uminho. pt/Textos_de_Trabalho/textos/dircriencpropar.pdf $>$. Acesso em: jun. 2010.

SOUZA, S. Crianças e adolescentes: construção histórica e social das concepções de proteção, direitos e participação. In: ENCONTRO "CRIANÇA E ADOLESCENTE: DIREITOS E SEXUALIDADE”, 5 nov. 2008, São Paulo. Anais... São Paulo: Associação Brasileira de 
Magistrados, Promotores de Justiça e Defensores Públicos da Infância e Juventude, Instituto WCF-Brasil, 2008. v. I. p.7-I5.

SPOSITO, M. P. A Pesquisa sobre jovens na pós-graduação: um balanço da produção discente em educação, ciências sociais e serviço social (1999-2006). In: SPOSITO, M. P. (Coord.). Estado da arte sobre juventude na pós-graduação brasileira: educação, ciências sociais e serviço social ( 1999-2006), I Belo Horizonte: Argvmentvm, 2009. p. I7-56.

SPOSITO, M. P.; BRENNER, A. K.; MORAES, F. F. Estudos sobre jovens na interface com a política. In: SPOSITO, M. P. (Coord.). Estado da arte sobre juventude na pós-graduação brasileira: educação, ciências sociais e serviço social (1999-2006), I. Belo Horizonte: Argvmentvm, 2009. p. 175-212.

SPOSITO, M. P.; DE TOMMASI, L.; MORENO, G. G. Adolescentes em processos de exclusão social. In: SPOSITO, M. P (Coord.). Estado da arte sobre juventude na pós-graduação brasileira: educação, ciências sociais e serviço social (1999-2006), I. Belo Horizonte: Argvmentvm, 2009. p. $127-177$.

THÉRY, I. Le Demariage, justice et vie privée. Paris: Odile Jacob, 1996. Les Nouveaux droits de l'enfant, p.338-37l.

THOMPSON, J. B. Ideologia e cultura moderna: teoria social crítica na era dos meios de comunicação de massa. Petrópolis: Vozes, 1995.

VENTURA, M. Sexualidade e reprodução na adolescência: uma questão de direitos. In: ADORNO, R. C. F.; ALVARENGA, A. T.; VASCONCELLOS, M. P. C. Jovens, trajetórias, masculinidades e direitos. São Paulo: Fapesp, Edusp, 2005. p.3।-52.

ZALUAR, A. Cidadãos não vão ao paraíso. São Paulo: Escuta; Campinas: Unicamp, 1994.

Recebido em: julho 2010

Aprovado para publicação em: julho 2010 